\title{
Thinking Against Humanity
}

\author{
Ayça Çubukçu ${ }^{1}$ \\ London School of Economics and Political Science
}

Forthcoming in 2017

The London Review of International Law

From its enlightened past, the modern world inherited the moral imperative to reduce human suffering anywhere in the world, with violence and cruelty when necessary. ${ }^{2}$ To understand how compassion and violence, benevolence and cruelty could be intimately intertwined, one may study practices of European colonizing missions which enfolded the native violently, with an idealist benevolence to better her lot in the eyes of God or of History, understood, of course, progressively. ${ }^{3}$ Even in colonial wars of extermination, what Paul Gilroy

\footnotetext{
${ }^{1}$ Acknowledgements: This essay benefited from the feedback of many friends and colleagues. In particular, I would like to thank Gil Anidjar, Talal Asad, Jared Ball, Anna Bernard, Partha Chatterjee, Carrie Friese, Stefanos Geroulanos, Sinja Graf, Itamar Mann, Geoffrey Waite and Gary Wilder for their helpful comments on earlier versions of this essay. I am also grateful to audiences at the Institute for Global Law and Policy at Harvard Law School, the Critical Theory Workshop held at the Inter-University Center of Dubrovnik, the Department of Sociology at the University of Warwick, the Centre for Critical International Law at Kent Law School, and the Department of Sociology at LSE for their critical feedback on various sections of this essay.
}

${ }^{2}$ See, among others, an important essay by the anthropologist Talal Asad, which argues that the heritage of the Enlightenment for the modern world is not merely the moral standard that universal suffering should be reduced, but also 'a complex genealogy that is partly older than the eighteenth century in which compassion and benevolence are intertwined with violence and cruelty, an intertwining that is not merely a coexistence of the two but a mutual dependence of each on the other'. T Asad, 'Reflections on Violence, Law and Humanitarianism' 41(2) Critical Inquiry (2015) 393. For a history of humanitarianism from early $19^{\text {th }}$ century to the present day, see M Barnett, Empire of Humanity: A History of Humanitarianism (Cornell UP, 2011). ${ }^{3}$ As Gayatri Spivak insists, the colonizers, too, were people with 'good intentions'. G Spivak, Critique of Postcolonial Reason: Towards a History of the Vanishing Present (Harvard UP, 1999) 371. Also see K Mantena, Alibis of Empire: Henry Maine and the Ends of Liberal Imperialism (Princeton UP, 2010) for a demonstration of how the $19^{\text {th }}$ century turn to indirect 
calls that ultimate colonial fantasy of a clean war infused violence with the high moral ground of humanity, of acting humanely in the name of civilization. ${ }^{4}$ In 1876, the notorious King Léopold II of Belgium's bloody empire could claim about his colonial enterprise in Africa, for instance, that it was 'charitable' and 'philanthropic', and that it brought together 'friends of humanity' in order 'to open to civilization the only part of the globe where it has not yet penetrated, to pierce the darkness enshrouding entire populations, that is, if I may venture to say so, a crusade worthy of this century of progress'. And 'the current is with us', King Léopold II would declare. ${ }^{5}$

Has the current ever left them? As a contemporary iteration of that ultimate colonial fantasy of a clean war, consider the following statement by the political theorist Michael Ignatieff, as inflicted as it is with the theological themes of mercy, benevolence, and the threat of a guilty conscience - all of which belong to the Christian just war tradition. In an article penned a few weeks after 11 September 2001, Ignatieff claimed:

We owe them [terrorists] nothing other than the mercy that all human life has a right to claim. But we owe ourselves much more. ... The obligations we owe are to ourselves alone, to the moral identity that gives justice to the cause. The combatants who will wage this war in our name will have to live with what they do. To execute the innocent, to visit death on civilians, even to torture the guilty, would haunt those who serve in our name. For that reason alone, a war against terror must be discriminate, proportional and restrained. ${ }^{6}$

rule in British India went along with the benevolent desire to defend 'native culture' from the disruptive effects of modernity.

${ }^{4}$ P Gilroy, Postcolonial Melancholia (Columbia UP, 2005) 43.

${ }^{5}$ Cited in Gilroy (2005) 60.

${ }^{6}$ M Ignatieff, 'It's war - but it doesn't have to be dirty', The Guardian, 1 October 2001, available at https://www.theguardian.com/world/2001/oct/01/afghanistan.terrorism9 (last visited 3 November 2016). Thanks to Paul Gilroy for drawing attention to this article by Ignatieff. For a 
Nevertheless, Ignatieff and other liberal-minded 'friends of humanity' cannot quite explain why it may be more acceptable to execute terrorists than to torture them cruelly. In either case, the terrorist appears as a gangrene to be cut off compassionately in order to improve the life of humankind as such.

It would be a mistake to dismiss such benevolent calls to violence for improving the life of humanity as mere 'rhetoric'. Instead, compassionate calls to arms - whether military interventions demanded, left and right, in the name of humanity or the endorsement of humane kinds of violence by human rights advocates, always discriminate, proportional, and timelydemonstrate how benevolence and violence can mutually depend on each other. ${ }^{7}$ We could remember that like the gas chamber that kills bloodless, the guillotine as well was a humane invention designed to kill in the name of a revolutionary humanity. ${ }^{8}$ After all, revolutionary love too can embrace violence benevolently (and vice versa). Essentially, it is in the context of this complex genealogy where compassion and violence feed on each other that I think we must reflect on the politics of humanity, and explore why - and with which consequencesinternationalists and cosmopolitans alike champion it.

With concerns that emanate from this context, in Part I, 'The Right to Be a Human Being', I begin the essay by examining how two contemporaries, Malcolm X and Hannah Arendt,

critique of the humanitarian (and Christian) just war tradition and its alleged difference from terrorism, see T Asad, On Suicide Bombing (Colombia UP, 2007). See also T Asad, 'Thinking about Terrorism and Just War' 23 (1) Cambridge Review of International Affairs (2010). Also note the interesting argument made by Whitman that humanitarian approaches to war as evil have made war ever more violent by invalidating war's pre-modern capacity to adjudicate and declare the conclusion of political conflict. J Whitman, The Verdict of Battle: The Law of Victory and the Making of Modern World (Harvard UP, 2012).

${ }^{7}$ A Çubukçu, 'The Responsibility to Protect: Libya and the Problem of Transnational Solidarity' 12 The Journal of Human Rights (2013) 40, 58.

${ }^{8}$ See M Foucault, Discipline and Punish: The Birth of The Prison (Penguin Books, 1991) [1997] 12-13. 
approached the question of human rights to reflect on the ways in which they challenge liberal formulations of rights that allegedly belong to all human beings by the mere fact of their birth. I argue that when liberal philosophies of human rights inscribe particular qualities to human beings (be it agency, autonomy, rationality, or whichever other quality is thought to differentiate humans from non-humans), they construct the human as potentially autonomous, developed, capable, rational, civilized, and therefore potentially entitled to and capable of enjoying human rights.

In Part II, 'The Essence of Humanity', contrary to common interpretations based on the concept of exclusion, I further develop my argument that the establishment of hierarchies amongst subjects with different entitlements to enjoy the human prerogative has also been facilitated by their categorical inclusion in the order of humanity-specifically, within an evolutionary framework that recognizes their potential to become proper humans. I conclude the article in Part III, 'Taking the Risk of Humanity', by questioning the desire for humanity as a collective subject. If, as I argue, violence is central, and hierarchy is intrinsic to the political and ethical operations of 'humanity' — why should the grounds of our acting together, with or without borders, be given by this concept? Considering the systematic nature of methods by which equality has been denied to certain human beings whose humanity, as membership in a species, has nevertheless been granted, I ask, what accounts for the faith that as concept, ideal, or practice, a humanity that does not discriminate amongst its ranks is possible?

\section{Part I}

\section{The Right to Be a Human Being}


On 28 June 1964, on the occasion of the Organization of Afro-American Unity's constitution in Harlem, Malcolm X, now in the last year of his life, declared a few rights, which were rights, he said, to be brought into existence—-by any means necessary.

We declare our right on this earth to be a man, to be a human being, to be respected as a human being, to be given the rights of a human being in this society, on this earth, in this day, which we intend to bring into existence by any means necessary. ${ }^{9}$

What is striking about this declaration is first and foremost the finding that man is not already man (not to mention woman ${ }^{10}$ ), that certain human beings are not already human beings. This is why Malcolm X finds it necessary to first speak of a right to be a man, of a right to be a human being, and only then of a right to be respected as a human being. ${ }^{11}$ In this conception, being human is a status to be brought into existence one way or another, but significantly, the human status cannot be established by the naked fact of birth.

Next comes an equally striking right, the right to be given the rights of a human being. Despite their similarity at first glance, this particular right Malcolm X articulates necessitates a

\footnotetext{
${ }^{9}$ M X, By Any Means Necessary: Speeches, Interviews, and a Letter by Malcolm X (Pathfinder Press, 1970) 56.

${ }^{10}$ Of course, it is not merely a coincidence that Malcolm X speaks first of a 'right to be a man' and then of a 'right to be a human being'. In addition to Malcolm X's own masculinist tendencies, moreover, consider Wendy Brown's argument that the 'liberal discourse of generic personhood reinscribe[s] rather than emancipate[s] us from male dominance'. W Brown, States of Injury: Power and Freedom in Late Modernity (Princeton UP, 1995) 141.

${ }^{11}$ With his formulation of a right to be a human being, Malcolm X may also be stressing the importance of particular forms of social behavior (acting with humanity). The fact that 'humanity' has this second sense of acting with kindness allows its meaning in discourse to slide from the one to the other. It seems to me that Malcolm X's notion of 'the right to be respected as a human being', which follows the 'right to be a human being', encapsulates better the socio-behavioral sense of 'humanity', as in acting kindly.
} 
politics quite different from Hannah Arendt's notion of the right to have rights. ${ }^{12}$ When Arendt wrote about the right to have rights - also in New York City, some ten years before Malcolm $\mathrm{X}$ - what she had in mind was the right to belong to a bounded political community, the right to legal membership in a particular polity. In the aftermath of the Second World War, Arendt would observe not only how the loss of 'national rights' always entailed the loss of human rights, but also how 'the restoration of human rights, as the recent example of the State of Israel proves, has been achieved only through the restoration or the establishment of national rights' ${ }^{13}$ More precisely then, what Arendt had in mind with her 'right to have rights' was citizenship (or 'nationality ${ }^{14}$ in the language of the Universal Declaration of Human Rights, and many a visa application today), the right to be a citizen of a state, which was the only practicable way, Arendt insisted, to enjoy human rights as civil rights protected by one's own state.

For Malcolm X, on the other hand, precisely the fact that Afro-Americans were citizens of the United States and thus subject to its racist rule of law was what prevented them from enjoying human rights. This is why Malcolm X found it necessary to situate his friends as well as his enemies within a global community that went beyond the United States into a transnational community of 'humanity'. But to be a member of this humanity, one still had to have, first and foremost, the right to be a human being, which was a 'right' that Malcolm X could take for granted neither in theory, nor in practice.

\footnotetext{
${ }^{12}$ It is remarkable indeed that despite the entanglement of their worlds, these two contemporaries are rarely discussed together. For a notable exception, see T Asad, 'Redeeming the "Human" Through Human Rights', in Formations of the Secular: Christianity, Islam, Modernity (Stanford UP, 2003).

${ }^{13} \mathrm{H}$ Arendt, The Origins of Totalitarianism (Harcourt, 1951) 299.

${ }^{14}$ For a meticulous interpretation of Arendt's 'right to have rights' from the perspective of international law, see A Kesby, Right to Have Rights: Citizenship, Humanity, and International Law (Oxford UP, 2012).
} 
What is more, when he declared on behalf of the Organization of Afro-American Unity then being founded in June 1964, this right to be a human being, Malcolm X articulated a conception of human rights that departs explicitly from its hegemonic, liberal versions. To this day, one of the most powerful assumptions predicating the idea of human rights is an assumption that, for all its appeal, contradicts the primary fact upon which Malcolm X declares a right to be a human being - namely, his finding that certain human beings are not already human beings, that they are in need of a right to be a human being. Liberal philosophies of human rights cannot accommodate such findings, at least not with ease. Instead, they insist, in perfectly circular fashion, that all humans beings are born as human beings, and as such, all humans are always and already entitled to human rights by the mere fact of their birth and their life.

But why then do debates about the human rights of the unborn, of the dead and the nearly dead, or of others found to display 'suboptimal' or 'underdeveloped' human qualities—such as infants, children, women, the disabled, the mad, and the colonized—why do they raise difficult problems for liberal human rights thought? This is the case because while on the one hand, liberal articulations of human rights are 'founded' on the assumption that one is born a human being, and therefore entitled to human rights by birth, on the other hand, such conceptions of human rights attach particular qualities to the concept and person of the human. ${ }^{15}$

As the philosopher James Griffin, a celebrated contemporary theorist of human rights admits, 'an account of human rights will have to [provide] an explanation of what it is about

\footnotetext{
${ }^{15}$ While this point has been well established by many scholars (see P Fitzpatrick, Modernism and the Grounds of Law (Cambridge UP, 2001)), for my argument, particularly relevant is Balibar's observation that the concept of the human always already bears within it ideas of the superhuman and the subhuman. E Balibar, 'Racism as Universalism', in Masses, Classes, Ideas (Routledge, 1994).
} 
being 'human' in virtue of which all human beings have these rights'. ${ }^{16}$ Accordingly, many liberal philosophers (whether they admit this explicitly or not) venture to provide a substantive account of the human — what one may call a universal anthropology of the human —in order to justify both the asserted universality and the specific content of human rights. ${ }^{17}$ For this purpose, Griffin develops the notion of personhood to name what all humans allegedly value in their 'status as human beings', which is a human status, he finds, that 'centers on our being agentsdeliberating, assessing, choosing and acting to make what we see as a good life for ourselves'. ${ }^{18}$

However, as Griffin and other liberal theorists have to admit — and this is key — the “"human" cannot there mean ... simply being a member of the species homo sapiens'. ${ }^{19}$ For one, Griffin explains this is the case - that the human cannot simply mean a member of the species homo sapiens - because although 'infants, the severely mentally retarded, people in irreversible coma are all members of the species', such persons are not 'functioning human agents'. ${ }^{20}$ In other words, only those who are proper agents are proper humans and hence the proper holders of human rights. My point here is not only to contest the accuracy of liberal philosophers' account of the human, but to demonstrate how the very inscription of particular qualities to human beings (be it agency, autonomy, rationality, or whichever other quality is thought to differentiate humans from non-humans) helps construct the human as potentially autonomous, developed, capable, sane, rational, civilized, and therefore potentially entitled to and capable of enjoying

${ }^{16}$ Cited in R Crips, 'Two Approaches to Human Rights', in R Crips (ed.), Griffin on Human Rights (Oxford UP, 2014) 3.

${ }^{17}$ For an instructive engagement with another influential account of the human, see Asad's deconstruction of Martha Nussbaum's universal anthropology. Asad (2003) 149-150.

${ }^{18}$ J Griffin, On Human Rights (Oxford UP, 2008) 32.

${ }^{19}$ Ibid 34.

${ }^{20}$ Ibid 34-35. 
human rights. Human rights, in other words, are the potential rights of proper human beings, where the proper criterion for establishing one's human status varies.

Here, it is relevant to observe as well how anthropologists themselves have contributed to the emergence of humanity as a potential to be cultivated, as the potential of particular and proper human qualities to develop and be developed. Consider the 'Declaration on Anthropology and Human Rights' adopted by the American Anthropological Association (AAA) in 1999. The preamble of the Declaration asserts that anthropology as a profession is committed to 'the right of people and peoples everywhere to the full realization of their humanity'. The Declaration further equates 'full realization of humanity' with what it calls a 'capacity for culture', which is a capacity that needs protection as well as promotion..$^{21}$ Incidentally, other concepts of human flourishing — including Marxist ones — may be thought as parts of the same, even if diverse, modern humanist tradition, a tradition which aims to cultivate an unalienated, capable, and proper humanity, however understood. ${ }^{22}$ Strikingly, in these humanist formulations, what all humans around the world share is a capacity for humanity: what is common to humans is, primarily, a potential humanity that requires cultivation, development and fostering. The point about potentiality is important, not only because it allows the modern conception of human rights to maintain an appearance of consistency in the face of human beings who are not found to be fully entitled to human rights (such as children, slaves, migrants or 'terrorists') but also because

${ }^{21}$ American Anthropological Association. 'Declaration on Anthropology and Human Rights', 1999, available at http://humanrights.americananthro.org/1999-statement-on-human-rights/ (last visited 3 November 2016).

${ }^{22}$ On the compatibility of Marxism and the human rights project of cultivating a proper humanity, see B Roth, 'Marxian Insights for the Human Rights Project', in S Marks (ed.), International Law on the Left: Re-Examining Marxist Legacies (Oxford UP, 2008). For a powerful refutal of humanism as a legitimate part of the Marxist tradition, see Louis Althusser's 'Marxism and Humanism'. L Althusser, 'Marxism and Humanism', in For Marx (Verso, 1996) [1964]. 
it allows human rights to present itself as a project of redemption, as a redemptive political project which aims to craft a new, better, more moral and less cruel humanity. ${ }^{23}$

Still, in its hegemonic, liberal version, human rights are the birth-rights of all humans who are born as human beings. It is precisely this loaded assertion that Malcolm X unsettles with his declaration of the very need for a right to be a human being, whereby he acknowledges the political fact, if I can speak this way, that certain human beings are not already human beings. They need the right to be a human being in order to become one. And how will they get it, this right to be a human being, and the particular right which follows from that in Malcolm X's formulation, the right to be given the rights of a human being?

Such a right is what Arendt may have had in mind when she asserted a 'right to have rights'. Nevertheless, what we have in Arendt's conception of the right to have rights is as much a condemnation of the failure of human rights to actualize in practice as a counter-assertion of the figure of the citizen against the human, and an endorsement of the framework of citizenship as the practicable, even the proper way to enjoy human rights. ${ }^{24}$ While it may not be a misjudgement to argue that after all, both Malcolm X and Hannah Arendt argued for the right to be given the rights of a human being, we must nevertheless admit that Arendt's preference for civil rights over human rights was coloured by the republican, as well as the civilizational — and

${ }^{23}$ On human rights as a redemptive project aimed at crafting a new humanity, see Asad (2003); Asad (2015).

${ }^{24}$ Consider this case made by Malcolm X, as if he were responding to Arendt, along with other advocates of civil rights over human rights: 'The American black man is the world's most shameful case of minority oppression. What makes the black man think of himself as only an internal United States issue is just a catch-phrase, two words, "civil rights". How is the black man going to get "civil rights" before he wins his human rights? If the American black man will start thinking about his human rights, and then start thinking of himself as one of the world's great peoples, he will see that he has a case for the United Nations'. M X \& A Haley, The Autobiography of Malcolm X (Grove Press, 1996) 274-275. It is notable that in his formulation, Malcolm X is appealing to a collectivist and not individualistic notion of human rights as he speaks of the minority status of African-Americans as a distinct people. 
dare I say, racist—-patterns of her thought. ${ }^{25}$ These patterns inform many of her problematic assertions in The Origins of Totalitarianism, for example that 'only savages have nothing more to fall back upon than the minimum fact of their human origin' and that 'natural rights are granted even to savages ${ }^{\prime}{ }^{26}$ where the racialized savage appears as the ontologically lowest member of a hierarchically imagined humanity. ${ }^{27}$

The savage, in other words, in his 'abstract nakedness of being nothing but human'28 becomes a manifestation of bare life as such in the imagination of Arendt - mere human life that approaches animality in its divorce from any remnant or achievement of civilization—and emerges as the embodiment of all that is not properly political within her philosophical framework. It is not a coincidence after all that Arendt chooses to reflect on a particular passage from Joseph Conrad's Heart of Darkness in her own masterpiece, The Origins of Totalitarianism, a passage where to a white European, precisely the fact that Africans are not not human beings becomes the most disturbing fact: 'No, they were not inhuman. Well you know, that was the worst of it - this suspicion of their not being inhuman', observes Arendt quoting Conrad. ${ }^{29}$ It is in this civilizational, racialized and supremacist framework that both the savage and the animal

${ }^{25}$ It is remarkable that otherwise perceptive students of Arendt's 'right to have rights' fail to take seriously (when they do not ignore it all together) the civilizational infliction of Arendt's thinking on this subject. See, for example, E Balibar, '(De)Constructing the Human as Human Institution: A reflection on the Coherence of Hannah Arendt's Practical Philosophy' 74 (3) Social Research (2007) 727, 738; A Gundogdu, "Perplexities of the Rights of Man": Arendt on the Aporias of Human Rights' 11 (1) European Journal of Political Theory (2012) 4, 24. For a systematic treatment of Arendt's 'anti-black racism' that goes beyond the common and limited focus on Arendt's 'Reflections on Little Rock' (H Arendt, 'Reflections on Little Rock' Dissent (1959) 45, 56), see K Gines, Hannah Arendt and the Negro Question (Indiana UP, 2014).

${ }^{26}$ Arendt (1951) 300 (emphases added).

${ }^{27}$ Gilroy shows how blackness can connote 'the unadorned inferiority of "bare life" on the lowest rungs of humanity's ontological ladder' (Gilroy (2005) 37), where the black body appears as ultimately biopolitical and racialized mere life, the very embodiment of an ontology of bare life. Arendt saw exactly this, it seems to me, in the figure of the savage.

${ }^{28}$ Arendt (1951) 300.

${ }^{29}$ Ibid 190. 
become markers of what Arendt finds despicable in human rights advocacy, when she observes with great disdain, for instance, how human rights campaigns between the two world wars showed 'an uncanny similarity in language and composition to that of societies for the prevention of cruelty to animals' ${ }^{30}$

Note, moreover, that Arendt's preference for civil rights as opposed to human rights is based on the unstable assumption, nay assertion, that the primary function of the state is the protection of its citizens and their rights. ${ }^{31}$ But how and why could Hannah Arendt, writing as a denationalized German Jew who could barely escape Nazi Germany assert so? As I have argued elsewhere, Arendt was thoroughly invested in normative ideas about 'the rule of law' and made tortured efforts to save the law as such from the disrepute it had fallen due to the legality of the Final Solution. ${ }^{32}$ In her endeavour to save the name of law, Arendt resorted — though not without inconsistencies - to ideas of 'lawfulness' predicated on natural law, which corresponded, she claimed, to the positive law of 'normal legal regimes'. Presumably, it was this type of regime, certainly the United States, and not what she distinguished as 'criminal regimes' that would protect human rights as civil rights.

Malcolm X, on the other hand, as a black citizen of the United States, could not afford Arendt's constitutive assertion — that 'his' state's primary function was the protection of its

\footnotetext{
${ }^{30}$ Ibid 292.

${ }^{31}$ This reliance on the state for the protection of rights couples Arendt's Burkean critique of natural rights and leads Balibar to interpret her politics of human rights as 'an extreme form of institutionalism'. Balibar (2007) 729. For an articulation of this 'institutionalism', note Arendt's finding that 'The Rights of Man, after all, had been defined as "inalienable" because they were supposed to be independent of all governments; but it turned out that the moment human beings lacked their own government and had to fall back upon their minimum rights, no authority was left to protect them and no institution was willing to guarantee them'. Arendt (1951) 291-292. 32 A Çubukçu, 'On the Exception of Hannah Arendt' Law, Culture and the Humanities (2015). DOI:10.1177/1743872115588442.
} 
citizens and their rights. For this reason, in his inaugurating speech for the Organization of AfroAmerican Unity in 1964, he would challenge what is supposed to be the state's exclusive right and responsibility to protect its citizens, and call upon 'every Afro-American person and every Afro-American community in [the United States] to protect its people'. Challenging, in other words, the state's monopoly of a responsibility to protect its people — which is a monopoly that is also challenged by the so-called international community today-Malcolm X reminded his fellow friends both of their duty and their right to defend, not others, as in the Responsibility to Protect (R2P) doctrine of contemporary international law (which Arendt could conceivably support), but themselves. ${ }^{33}$

Still, in identical terms with its articulation in international law, Malcolm X framed his version of the responsibility to protect doctrine as a necessary yet residual right and duty. As is the case with the jurisprudential rationale of the R2P, Malcolm X limited his community's (not the international community's but the Afro-American community's) responsibility to protect to 'those areas where the government is either unable or unwilling to protect' the lives of his people. ${ }^{34}$ But there is a second sense in which both versions of the $\mathrm{R} 2 \mathrm{P}$ - as a doctrine of just war developed by international law and as a doctrine of self-defence articulated by Malcolm $\mathrm{X}$ mobilize a necessary yet residual right and duty. They both proceed from the prior assumption that, in the words of Malcolm X, self-preservation is the first law of nature. 'Since self-

\footnotetext{
${ }^{33}$ For a critical engagement with the Responsibility to Protect doctrine, see A Orford, International Authority and the Responsibility to Protect (Cambridge UP, 2011). I have articulated my own interpretation of this dangerous doctrine in Çubukçu (2013).

${ }^{34}$ While Malcolm X's emphasis here is on the right to self-defense belonging to the AfroAmerican community in the United States, clearly, this right was situated within the larger context of his internationalist Pan-Africanism. Note moreover that Malcolm X's version of 'the international community' was quite different than the one underpinning contemporary invocations of R2P.
} 
preservation is the first law of nature, we assert the Afro-American's right to self-defence', would declare Malcolm X.

Now this is a law of nature that most modern thinkers from Thomas Hobbes to Hannah Arendt, as well as 'humanist lawyers' could agree with. In fact, self-defence lies at the foundation of modern political thought and the way it has conceptualized the very reason of the state, its raison d'état, the rationale for the very existence of the state. The principle of selfpreservation, in other words, grounds the necessity for the state, and its legal and extra-legal means for establishing 'peace and security'. Perhaps needless to say, from the United Nations to the North Atlantic Treaty Organization, all violent institutions of international law employ the violence of the law in the name of establishing 'peace and security', as they too constitute themselves on the pillars of this apparently natural need for, this apparently natural necessity of, self-preservation.

In fact, the very concept of necessity — as a modern legal and moral category — is linked intimately with the so-called natural law of self-preservation. The way in which Hannah Arendt distinguishes between the 'state crimes' of what she calls normal legal regimes (such as Israel) on the one hand, and the state crimes of criminal regimes (such as Nazi Germany) on the other, illustrates well the reasons for this finding. Within Arendt's differential scheme, in 'normal legal regimes', necessity dictates the commission of an exceptional criminal act by the state- which is a criminality that can neither be judged nor acted on by outside political entities, and this is so precisely because the state's unquestionable right to exist, its natural right to survive, is at stake. ${ }^{35}$ The reverse is the case in criminal regimes, Arendt would have us believe, because there, what

${ }^{35} \mathrm{H}$ Arendt, Eichmann in Jerusalem: A Report on the Banality of Evil (Penguin Books, 1994) [1965] 291. 
necessity dictates is not an occasional, exceptional criminal act by the state, but instead an exceptional lawfulness. ${ }^{36}$

If, for Arendt, state acts by 'normal legal regimes' which may be deemed criminal according to positive law can nonetheless remain lawful on account of the higher law of selfpreservation, the same is the case for Malcolm X when he reflects on the lawfulness of his own call to arms in a legal context where this call could be deemed criminal:

This is the thing you need to spread the word about among our people wherever you go. Never let them be brainwashed into thinking that whenever they take steps to see that they are in a position to defend themselves that they are being unlawful. The only time you are unlawful is when you break the law. It's lawful to have something to defend yourself. ${ }^{37}$

Here, the lawfulness articulated by Malcolm X concerns the principle of self-preservation above the particularities of posited law. But as he immediately reminds his audience, what he affirms as the lawfulness of self-preservation is already and routinely practiced, within the bounds of positive law, by the United States as well as other states around the world. In this context, the reason Malcolm X has to make an appeal to the natural law of self-preservation is simply that he is not the leader of a state, but of a political movement unable to mobilize positive law for the purposes of its self-defence.

All of this demonstrates that although they may ultimately envision different political arrangements as the best, Hannah Arendt and Malcolm X share a fundamental belief that colours their approach to the question of human rights. This is the principle of survival and its correlate, the right to self-defence, by any means necessary, including violent ones, legal or otherwise. But

\footnotetext{
36 Ibid.

${ }^{37} \mathrm{X}(1970) \mathrm{X}$.
} 
whereas Arendt may find in violence, as in human rights, an anti-political mantle ${ }^{38}$ except when employed by 'normal legal regimes', Malcolm X perceives in violence a method intimately linked with the goal of ensuring the very survival of his community as human beings. If, however, the necessity of self-preservation, if the necessity of survival underwrites the violence of the law and its humane principles—-whether in Israel, Harlem, or the United Nations Security Council — we may still wish to ask what accounts for the force of this necessity and its hold over our political imagination.

\section{Part II}

\section{The Essence of Humanity}

In the tradition of European humanism, the constitution of humanity as a collective subject—-for whom universal benevolence is to be practiced and a grand loyalty exercised - is partly founded upon humanity's difference from and superiority over animality. ${ }^{39}$ Hence, the orbit of the 'universal solidarity' which humanism draws excludes, at the outset, the animal. While humanist arguments are often made for the extension of care and solidarity to animals, it is their degree of similarity to humans — whether measured through animals' capacity to feel pleasure or pain or their intelligence - that grounds such pleas for the 'humane' treatment of animals. ${ }^{40}$ Significantly, these arguments leave intact the hierarchical positioning of the human

\footnotetext{
${ }^{38}$ See H Arendt, On Violence (Harcourt, 1970).

${ }^{39}$ See J Derrida, The Animal That Therefore I am (Fordham UP, 2008); G Agamben, The Open (Stanford UP, 2004).

${ }^{40}$ As Latimer demonstrates, while 'the reason for animals being folded into humanist ethics are complex', they nevertheless center on 'similitude'. J Latimer, 'Being Alongside: Rethinking Relations Amongst Different Kinds’ 30 (7-8) Theory, Culture \& Society (2013) 90.
} 
above the animal, while they also order different animal species hierarchically according to their various degrees of proximity to what is taken to be the essence of humanity. ${ }^{41}$ But that is not all.

Those subjects effectively banned from the category of the human — and hence the enjoyment of the prerogatives of the human status - have also included subjects who were at once acknowledged to be parts of humanity as a species. If, in the sense of the species, 'humanity was born and nurtured in the crucible of early modern conquest and settler colonialism', ${ }^{42}$ against familiar interpretations based on the concepts of dehumanization ${ }^{43}$ and exclusion, I would like to argue that those who could not fully enjoy the prerogatives of being human — be it women or the colonized, slaves or children—were deprived of this enjoyment not only when they were excluded from the category of the human, but when they were included within it as potential humans. ${ }^{44}$

In other words, it was (and is) their categorical inclusion in the order of humanity within an evolutionary framework that recognizes their potential to become proper humans (understood here as Christian, there as civilized, mature, moral, or rational) that has enabled the establishment of hierarchies amongst subjects with different entitlements to enjoy the human prerogative. As Antony Anghie ${ }^{45}$ demonstrates, the celebrated humanist jurist Vitoria justified the Spanish

${ }^{41}$ See C Friese, Cloning Wild Life: Zoos, Captivity and the Future of the Endangered Animals (New York UP, 2013) for a careful examination of how in zoos, different animals tend to be accorded varying degrees of freedom according to their proximity to certain 'human characteristics'.

42 Asad (2015) 398.

${ }^{43}$ For a critique of the concept of dehumanization, see S Esmeir, 'On Making Dehumanization Possible' 121 (5) PMLA (2006) 1544, 1551.

${ }^{44}$ Asad makes this point about potentiality in passing; see Asad (2015) 398. Also see S Esmeir, Juridical Humanity: A Colonial History (Stanford UP, 2012), which builds on Asad's work to demonstrate how it was not exclusion from, but inclusion in the category of the human that facilitated British ambitions in their colonization of Egypt.

${ }^{45}$ A Anghie, Imperialism, Sovereignty and the Making of International Law (Cambridge UP, 2005). 
colonization of the Americas precisely by acknowledging the rationality, that is, the perfectibility and "human potential" of the native. ${ }^{46}$. In the case of British rule over India, to give another example, what Partha Chatterjee calls the two strategies of empire-the pedagogy of violence and the pedagogy of culture - were employed over the colonized in order to bring her closer to the order of proper humanity, or what Chatterjee prefers to call 'the norm' ${ }^{47}$ Here, as elsewhere, pedagogical violence was to be received by insufficiently proper humans — who lacked Christianity, civilization, culture, rationality, or the correct ideology — as a gift of love, a violent, yet redemptive and liberatory love for the development of (their) humanity.

That the modern concept of humanity can simultaneously designate a collective subject to be redeemed, liberated, defended, and developed through various ethico-political projects on the one hand, and an apparently self-evident, all-embracing human species on the other hand — that duality is enabled by the common assumption that members of humanity share a singular essence. And this duality appears beyond the liberal tradition, when we consider, for example, the Marxist concept of alienation ${ }^{48}$ and its development by anticolonial thought as exemplified by Frantz Fanon's call for disalienation, by which he meant the 'the unmaking of racialized bodies and their restoration to properly human modes of being in the world'. ${ }^{49}$ Here, as elsewhere, humanity appears at once as a fact (because the human status of the racialized body is not in question), as

\footnotetext{
${ }^{46}$ A Anghie, Imperialism, Sovereignty and the Making of International Law (Cambridge UP, 2005) 22-23.

${ }^{47}$ P Chatterjee, The Black Hole of Empire: History of a Global Practice of Power (Princeton UP, 2012); P Chatterjee \& A Çubukçu, 'Empire as a Practice of Power: An Interview', Humanity Blog, 28 August 2012, available at http://humanityjournal.org/blog/empire-as-a-practice-ofpower-empire-as-ideology-and-as-technique/ (last visited 3 November 2016).

${ }^{48}$ Note, however that Althusser dismisses the concept of alienation altogether as 'pre-Marxist'. This did not mean, however, that Althusser divorced Marxism from an ideological process through which humans were to be formed and transformed in order to prepare them 'to respond to the demands of their conditions'. Althusser (1996) [1964].

${ }^{49}$ Gilroy (2005) 42 (emphasis added).
} 
much as an ideal (because the colonized is not living a properly human life). Revealing the full ambition of his anti-colonial thought, when addressing his comrades, Fanon would go as far as to demand that 'we ought to uplift the people... we must ... change them, and make them into human beings' ${ }^{90}$ To make the colonized into human beings —-how different was this call from the colonial mission of bourgeois humanism we might still ask, which, according to Fanon himself, managed 'to appear logical in its own eyes by inviting the sub-men to become human?' ${ }_{51}$ And in Fanon's project of making humans, of turning the colonized into human beings, how did the role of violence differ from that which the colonizer assigned to it—beyond, that is, a change in the subject who was to be in charge of it? $?^{52}$

Besides the idea of a singular human essence, the assertion that humanity shares a common human experience also facilitates the duality I wish to elucidate. As Talal Asad observes, the idea of a common human experience-the human experience-emerged among writers in nineteenth century England and like the idea of the human essence, it began to refer, en masse, to lives of individuals regardless of their 'accidental' particularities ${ }^{53}$ such as their class, race, culture, gender and even times. As such, the idea of a secularized human experience 'became a way of talking about the essence of humanity', a human essence that was seen at once

${ }^{50}$ F Fanon, The Wretched of the Earth (Penguin Books, 1990) [1965].

${ }^{51}$ Ibid 131.

${ }^{52}$ Butler is right to insist that we have to understand "whether violence is generative of a "new man"' for Sartre and Fanon, and that the answer may be yes in both cases. J Butler, Senses of the Subject (Fordham UP, 2015) 182. However, I find it difficult to agree with Butler that Sartre, through Fanon, is thereby offering a 'new humanism to confound the old, one that requires, under these social conditions, violence to materialize' for I am not convinced that the old humanism did not require violence. Ibid 187. Moreover, we must still ask what is 'new' in the humanism of Sartre and Fanon, and why the universality that Fanon is calling for is to be understood as a 'new universality'. Ibid 196. Through which criteria could such newness be established? With these questions in mind, Butler's own probing as to 'why violence appears as the route toward selfhood, agency, and even life' in Fanon, and whether it is the only route appears doubly important. Ibid 185.

${ }^{53}$ Asad (2015) 396. 
as universal and historical. ${ }^{44}$ In this way, Asad further argues, the very notion of the human experience helped translate natural law as divinely inscribed morality 'into a secular device for relating the plurality of the world's customs to the universality of transcendent law'.55

I would like to frame this slightly differently: on the one hand, the idea of humanity's universal essence grounds the very applicability of universal law to humanity as a collective subject. At once, what is understood to be humanity's historically contingent, varying constitution - the notion of a historical human essence-allows diverse human practices various degrees of alignment with universal law, and enables the differential placement of particular human practices along universal standards of 'progress'. In any case, the idea of the human essence - whether understood universally, historically, or through a combination of the tworemains central to the idea of humanity as a collective subject, be it humanity 'as the hero of a narrative in which liberty continually expands ${ }^{{ }_{56}}$ or humanity as the universal victim of a particular crime. ${ }^{57}$ Without the idea of the human essence, humanism and humanist projects of evolution and revolution could not make much sense of humanity: neither as a species, nor as a collective subject to be cultivated, redeemed, liberated, or defended.

\section{Part III}

\section{Taking the Risk of Humanity}

\footnotetext{
54 Ibid.

55 Ibid 397.

56 Ibid.
}

${ }^{57}$ Although she does not discuss how the notion of the human essence contributes to its normative construction, Graf demonstrates well how the notion of humanity that underwrites the legal concept of 'crimes against humanity' is not descriptive but thoroughly normative. S Graf, 'To Regain Some Kind of Human Equality: Theorizing the Political Productivity of "Crimes Against Humanity"', Law, Culture and the Humanities (2015). DOI: $10.1177 / 1743872115612326$. 
Much has accumulated against humanity, against those who arrogate themselves to be acting on its behalf: at least as much death and destruction as beauty, creativity, solidarity. ${ }^{58}$ Still, humanity's well-intentioned advocates are many. But is the concept of humanity necessarily, intrinsically, or 'really' as harmless as its passionate advocates claim? And if humanity is an allinclusive concept that excludes the exclusion of any human being, why is the history of humanity—as concept, ideal, and political subject—full of exclusions from its ranks, chaining together one subhuman to another?

I speak of subhumanity here rather than 'inhumanity' or 'dehumanization' for a number of reasons. First, positing what is essentially the problem of equality among human beings as one of 'inhumanity' or 'dehumanization' contributes to a tradition of thought according to which racism, for example, is rooted in exclusion from the order of humanity. According to this line of thinking, 'humanization' would be a solution to racism because it would facilitate the inclusion of those subjected to racism within the category of the human and 'the family of humanity' (as the Universal Declaration of Human Rights calls it). In other words, when various propagations of hierarchy, including racism and sexism, are diagnosed as dehumanization, 'humanization'59 (whatever that may involve) is quickly asserted as the means to equality among human beings.

\footnotetext{
${ }^{58}$ Observe how the concept of humanity currently tends to operate: 'Now, over the last few decades, as the various global crises have been accumulating - climate change, the threat of nuclear war as well as the dangers of nuclear energy, the uncontrollability of the global financial system, and so on - we now hear people saying things like: "Look at what humanity has done". Now suddenly the subject is "humanity", whereas originally, Euro-Americans had claimed: "Look at the stunning achievements of the West"'. T Asad \& H Azad, 'Being Human: An Interview with Talal Asad', The Islamic Monthly, 20 October 2015, available at http://theislamicmonthly.com/being-human-an-interview-with-talal-asad/ (last visited 3 November 2016).

59 Thinking critically about what projects of humanization may involve, Butler observes that 'if emasculation is the sign of dehumanization, then the masculine is the presumptive norm of humanization' Butler (2015) 197, whereby one may be tempted, like Fanon, to establish 'human dignity through masculinization'. Butler (2015) 175.
} 
But this tradition of thinking ignores the fact that the ideal of humanity and its conceptual and practical history have also involved the withdrawal of solidarity and the denial of equality to certain human beings whose humanity, as membership in a species, was nevertheless granted. This fact is what Sartre recognizes in his preface to Fanon's Wretched of the Earth, when he translates what the colonized are saying to Europeans: 'Your humanism claims we are at one with the rest of humanity, but your racist methods set us apart' ${ }^{90}$ Given the systematic nature of methods by which solidarity has been withdrawn and equality denied to certain human beings whose humanity as membership in a species has nevertheless been granted, what accounts for the faith that as concept, ideal, or practice, a humanity that does not discriminate amongst its ranks is possible? Perhaps more importantly, what accounts for the very desire for humanity as a collective subject when it introduces hierarchies within and between 'species'?

Thinking against humanity is not thinking against solidarity or equality, nor is it refusing to act for a justice without borders. Thinking against humanity affirms the need for creating a common ground and horizon of political action in terms of what we want and do not want to see happen on this earth, whoever this 'we' may be, when certainly, we are not unified as one humanity. Would such a unified humanity be desirable in the first place: should solidarity be extended to all human beings regardless of their particular deeds and dreams? And if, as I have argued, violence is central and hierarchy is intrinsic to the political and ethical operations of humanity — hierarchies between proper humans and improper ones, however defined; hierarchies between fully developed humans and those not yet fully developed, however understood;

${ }^{60}$ J-P Sartre, 'Preface', in F Fanon, The Wretched of the Earth (Penguin Books, 1990) [1965] 8. In fact, civilizational justifications of colonialism have always maintained that "colonization is a precondition for humanization'. Butler (2015) 184. 
hierarchies between humans and non-humans - why should the grounds of our acting together, with or without borders, be given by this concept of 'humankind'? ${ }^{61}$

What is more, when practicing principles of equality and solidarity across species, this we could do without claiming membership in that part of humanity, proper humanity, which becomes proper at the expense of others who remain not properly human. Instead, we could constitute, when acting in concert, measures of justice that we want to live by, humans and nonhumans alike, and build the political and ethical communities that we wish to nurture and defend — with some means and not unnecessary others. ${ }^{62}$

We cannot afford to talk carelessly about universal solidarity with humanity as if humanity were a self-evident, innocent community to be in solidarity with. On the contrary, what Hannah Arendt observed some fifty years ago may still the case: 'The idealism of the humanist tradition of Enlightenment and its concept of mankind look like reckless optimism in the light of present realities'. ${ }^{63}$ Perhaps, it is the case that 'the risk of casual talk about humanity' can be sanctioned, but as Paul Gilroy argues through Du Bois, only if 'the corrosive power of the broken world's racial order can be addressed seriously and consistently', once, that is, our underestimation of 'how much work needs to be done in order to repair and rework facile notions of human fellowship and solidarity' ceases to exist. ${ }^{64}$ Taking the risk of talking about humanity, if it is not going to be reckless, requires a preparedness to examine seriously and unapologetically the violent legacies of humanism, including its anti-colonial and anti-racist

\footnotetext{
${ }^{61}$ Politically correct renderings of 'mankind' into 'humankind' fail to erase the masculinist inflictions of this concept. See Butler (2015) 182-183.

${ }^{62}$ As Wendy Brown poignantly observes, human rights politics tend to prevent local deliberation by referring matters of debate to courts or transcendental principles. W Brown, 'Human Rights and the Politics of Fatalism: the Most We Can Hope For?' 103 (2-3) South Atlantic Quarterly (2004) 451, 463.

${ }^{63}$ H Arendt, Men in Dark Times (Harcourt, 1968) X.

${ }^{64}$ Gilroy (2005) 36 (emphasis added).
} 
kinds. And who will have the temerity to do that by sacrificing the 'absolutist or naturalized status' of the human and her rights ${ }^{65}$ Once that is attempted, perhaps then we could begin to honour 'the dark side' of humanity before proceeding proudly, almost perversely, to call people to humanity's name, to the violent love and law of humanity.

${ }^{65}$ See the original formulation of this question in W Brown, 'Suffering the Paradoxes of Rights', in W Brown \& J Halley (eds), Left Legalism, Left Critique (Duke UP, 2002). 